\title{
Perbedaan Exercise dan Pemeliharaan terhadap Waktu Tempuh dan Kecepatan Lari Sapi Karapan
}

\section{Differences of Exercise and Maintenance of Racing Cattle on Mileage and Running Speed}

\author{
A. K. Rahman, M. Mudawamah* dan S. Susilowati \\ Fakultas Peternakan Universitas Islam Malang, J1. MT Haryono 193 Malang \\ ${ }^{*}$ Corresponding e-mail : mudawamah@unisma.ac.id
}

\begin{abstract}
The purpose of this study was to determine mileage and running speed of racing cattle with the differences in exercise and maintenance in Bulangan Branta Village, Pegantenan District, Pamekasan Regency. The method used a case study and purposive sampling with criteria of racing type, Madura cattle, bulls aged 2-3 years. The research consisted of two treatment groups, namely group one (K1) with exercise (frequency) and maintenance (bathing, drying, massage and giving herbs) which were different from group two (K2), with a total of 20 cows. The variables observed were mileage and running speed which were calculated based on the same distance traveled, $222 \mathrm{~m}$. The data analysis used was the independent t-test using Ms. Excel. The results indicated that the average mileage for K1 cattle was 18.4 seconds and that for K2 was 20.8 seconds. Meanwhile, the average running speed of the $\mathrm{K} 1$ was $12.03 \mathrm{~m} / \mathrm{sec}$ and the $\mathrm{K} 2$ races were $10.69 \mathrm{~m} / \mathrm{sec}$. The conclusion is that the mileage and running speed of racing bull was higher significantly different in K1 (exercise) than K2 (maintanance).
\end{abstract}

Key words: exercise, maintenance, Madura cattle

\begin{abstract}
ABSTRAK
Tujuan penelitian ini adalah untuk mengetahui perbedaan terhadap waktu tempuh serta kecepatan lari dengan perbedaan exercise dan pemeliharaan pada sapi karapan di desa Bulangan Branta Kecamatan Pegantenan Kabupaten Pamekasan. Metode yang digunakan adalah metode studi kasus dengan pengambilan sampel purposive sampling dengan kriteria sapi Madura jantan tipe karapan dengan umur 2-3 tahun. Materi penelitian terdiri dari dua kelompok perlakuan yaitu kelompok satu (K1) dengan exercise (frekuensi) dan pemeliharaan (memandikan, penjemuran, pemijatan dan pemberian jamu) yang berbeda dengan kelompok dua (K2), dengan total sapi 20 ekor. Variabel yang diamati adalah waktu tempuh dan kecepatan lari yang dihitung berdarkan jarak tempuh yang sama yaitu $222 \mathrm{~m}$. Analisis data yang digunakan ialah independent $\mathrm{t}$ test menggunakan Ms. Excel. Hasil penelitian ini menunjukkan bahwa rataan waktu tempuh sapi karapan K1 adalah 18,4 detik dan sapi karapan K2 adalah 20,8 detik. Rataan nilai kecepatan lari sapi karapan K1 ialah 12,03 m/detik dan sapi karapan K2 ialah 10,69 m/detik. Dari hasil penelitian tersebut dapat disimpulkan bahwa rataan nilai waktu tempuh dan kecepatan lari sapi sangat berbeda nyata antara sapi karapan K1 (exercise) terhadap sapi karapan K2 (maintanance).
\end{abstract}

Kata kunci: exercise, pemeliharaan, sapi Madura

\section{PENDAHULUAN}

Indonesia mempunyai keanekaragaman budaya yang sangat unik salah satunya adalah karapan sapi. Karapan sapi merupakan salah satu wujud hasil budaya yang berupa kesenian yang mana karapan sapi termasuk salah satu jenis atraksi yang diangkat dari budaya Madura dan bentuk dari budaya tersebut adalah memperagakan lomba pacuan sapi yang memang khusus untuk dilombakan (Hefni, 2013). Pada awal perkembangannya, karapan sapi diselenggarakan untuk meningkatkan persahabatan dan kekeluargaan. Karapan sapi merupakan icon bagi masyarakat Madura dan merupakan bentuk simbol budaya yang dapat mengangkat harkat dan martabat masyarakat Madura. Karapan Sapi mengandung nilai-nilai yang bermanfaat untuk diketahui seperti kerja keras, kerjasama, persaingan, ketertiban, sportivitas, silaturahmi, dan sarana kebutuhan ekonomi bagi sebagian masyarakat Madura lainnya.

Menurut Kutsiyah (2014) karapan sapi merupakan budaya asli dari tanah Madura yang dikenal sejak abad ke-14 M. Pada zaman dahulu, sapi merupakan satu-satunya alat transportasi tercepat yang ada di Madura dan banyak 
digunakan oleh masyarakat khususnya masyarakat elit atau kerajaan. Karapan sapi ini merupakan salah satu contoh budaya dan hiburan bagi masyarakat Madura yang telah turun temurun dilaksanakan. Karapan sapi dibuat untuk membantu masyarakat Madura dalam melakukan interaksi dan komunikasi dengan orang lain. Interaksi dan komunikasi yang terjadi melalui budaya karapan sapi mengakibatkan terbentuknya kelompok sosial.

Adanya karapan sapi juga dapat memberi manfaat bagi peternak sapi karapan. Apabila sapi karapan salah satu peternak memenangkan perlombaan atau menjadi juara pada kontes karapan sapi maka kemenangannya akan berpengaruh terhadap harga jual sapi karapan tersebut. Harga jual sapi karapan yang memenangkan kontes dapat meningkat tiga kali lipat dari harga sebelumnya.

Untuk meraih juara dalam setiap even karapan sapi tidak mudah, apalagi di ajang karapan sapi dalam tingkat kabupaten (gubeng). Diperlukan usaha yang maksimal dari pemilik sapi karapan, mulai dari persiapan hingga pelaksanaan. Biaya perawatannya sangat besar. Sapi harus dipilih dari benih yang unggul dengan pemeliharaan yang ulet, telaten, sabar, dan ahli. Oleh karena itu, tidak jarang pemilik sapi harus merekrut peternak yang ahli dan telah paham benar dengan karakter sapi karapan. Pemeliharaan sapi karapan meliputi mandi, dijemur di bawah sinar matahari pagi, dipijat, diberi makan dan jamu-jamuan. Makanan utamanya adalah rumput, daun lamtoro, dan daun jagung muda yang selalu harus dalam keadaan segar. Salah satu hal penting yang harus diperhatikan oleh pemilik sapi karapan sebelum perlombaan adalah latihan. Sapi yang akan diikutkan dalam ajang karapan sapi tersebut harus menjalani latihan setiap hari dan dirawat secara baik. Selain itu sapi tersebut harus diberi jamu agar larinya gesit. Semakin sering sapi karapan dilatih, maka dapat memungkinkan pacuan sapi tersebut semakin cepat. Begitu pula para peternak sapi karapan yang ada di desa Bulangan Branta Kabupaten Pamekasan yang memiliki perlakuan exercise dan pemeliharaan yang berbeda terhadap sapi karapannya masingmasing.

Berdasarkan penjelasan diatas, peneliti merasa tertarik untuk melakukan penelitian tentang perbedaan exercise dan pemeliharaan terhadap waktu tempuh dan kecepatan lari sapi karapan di Desa Bulangan Branta Kecamatan Pegantenan Kabupaten Pamekasan.

\section{MATERI DAN METODE}

Metode yang digunakan dalam penelitian ini adalah metode studi kasus dengan pengambilan sampel purposive sampling di Desa Bulangan Branta Kecamatan Pegantenan dengan kriteria sapi karapan berumur 2-3 tahun. Jumlah sampel penelitian yang diambil dari dua peternakan sapi karapan dengan jumlah masing-masing sebanyak 10 ekor. Pemberian pakan dari kedua peternakan tersebut adalah daun lamtoro segar dengan jumlah 1,5 kilogram dan pemberian minum satu liter air setelah selesai makan. Data yang diperoleh akan dianalisis dengan metode indepent $t$ test atau uji $\mathrm{t}$ tidak berpasangan dengan menggunakan $M s$. excel.

- Sampel penelitian terdiri dari dua perlakuan yaitu:

1) Kelompok pertama (peternak 1, H. Rifqi): melakukan exercise dua hari sekali dengan pemeliharaan meliputi memandikan dan penjemuran 3 kali sehari (pukul 07.30, pukul 14.30 dan pukul 20.00), pemijatan setiap malam dan pemberian jamu setiap malam. Selanjutnya sampel dari kelompok pertama disebut perlakuan pertama (K1).

2) Kelompok kedua (peternak 2, H. Ahmad): melakukan exercise tiga hari sekali dengan pemeliharaan meliputi memandikan dan penjemuran 1 kali sehari (pukul 09.00), pemijatan tiga hari sekali dan pemberian jamu dua hari satu kali. Selanjutnya sampel dari kelompok kedua disebut perlakuan kedua (K2).

- Variabel penelitian yang diamati adalah:

a) Waktu tempuh lari sapi karapan, yaitu jumlah waktu yang diukur setelah sapi karapan berlari dalam jarak 222 meter.

b) Kecepatan lari sapi karapan, yaitu jumlah hasil perbandingan antara jarak tempuh (222 meter) dengan waktu tempuh lari sapi karapan.

Rumus perhitungan kecepatan lari sapi karapan sebagai berikut :

kecepatan rata rata $(\mathrm{V})=\frac{\text { jarak tempuh }(\mathrm{s})}{\text { waktu yang ditempuh }(\mathrm{t})}$ 


\section{HASIL DAN PEMBAHASAN}

Nilai rata-rata waktu tempuh dan kecepatan lari sapi karapan yang berlari dengan jarak 222 meter dapat dilihat pada Table 1 dibawah ini.

Tabel 1. Waktu tempuh sapi karapan yang berlari dalam jarak 222 meter

\begin{tabular}{ccc}
\hline Keterangan & $\begin{array}{c}\text { Sapi } \\
\text { Kelompok 1 } \\
(\mathrm{K} 1)\end{array}$ & $\begin{array}{c}\text { Sapi } \\
\text { Kelompok 2 } \\
(\mathrm{K} 2)\end{array}$ \\
\hline $\begin{array}{c}\text { Waktu } \\
\text { Tempuh } \\
\text { (detik) }\end{array}$ & $18,40^{\mathrm{a}} \pm 0,40$ & $20,80^{\mathrm{b}} \pm 0,95$ \\
$\begin{array}{c}\text { Kecepatan } \\
\text { lari (detik/m) }\end{array}$ & $12.03^{\mathrm{a}} \pm 0.26$ & $10.69^{\mathrm{b}} \pm 0.24$ \\
\hline
\end{tabular}

Keterangan: notasi yang berbeda pada baris yang sama berarti berbeda sangat nyata $(\mathrm{P}<0,01)$

Tabel 1 menunjukkan bahwa waktu tempuh dan kecepatan lari sapi karapan K1 sangat nyata $(\mathrm{P}<0,01)$ lebih rendah dan lebih cepat dibandingkan dengan K2. Besarnya perbedaan tersebut adalah sebesar 13,00 \% lebih tinggi sapi karapan K1 dibandingkan dengan K2. Ini berarti dalam jarak yang sama yaitu $222 \mathrm{~m}$ atau middle segment (Nielsen et al., 2006) sapi karapan K1 lebih pendek waktu tempuhnya dan lebih cepat larinya dibandingkan dengan sapi karapan K2. Sapi karapan K1 dalam 10 hari melakukan exersice 5 kali sedangkan K2 hanya 3 kali. Widi dan Hartatik (2009), kecepatan lari yang dimiliki sapi karapan bergantung pada olahraga seharihari. Sesuai dengan pendapat Aryogi dan Romjali (2006) menyatakan bahwa latihan lari secara berkala terhadap sapi karapan bertujuan untuk

Waktu Tempuh Lari Sapi Karapan (detik)

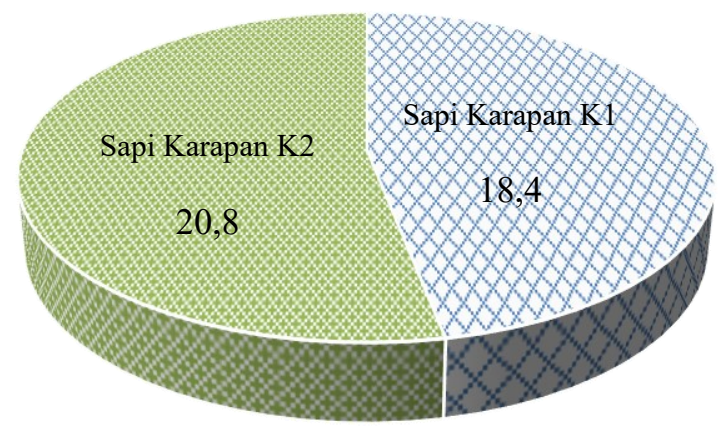

membentuk perilaku agresif yang akan mempengaruhi kecepatan serta lama waktu lari sapi karapan. Lama waktu latihan yang dilakukan secara berkala mampu meningkatkan kebugaran ternak yang ditunjukkan oleh suhu kulit, suhu rektal, denyut nadi, dan frekuensi nafas setelah uji pacuan (Sumadi et al., 2006).

Hasil analisa data yang dihitung melalui metode independent t-test menunjukkan bahwa nilai rata-rata waktu tempuh lari sapi karapan dengan pemeliharaan intens (K1) lebih rendah dari nilai rata-rata waktu tempuh lari sapi karapan dengan pemeliharaan yang kurang (K2). Nilai rata-rata kecepatan lari sapi karapan K1 lebih tinggi dibandingkan dengan sapi karapan K2. Dari kurva rataan waktu tempuh dan kecepatan lari sapi karapan diatas, dapat disimpulkan bahwa dalam jarak yang sama (222 m) sapi karapan K1 lebih cepat dan menghabiskan waktu tempuh lebih sedikit dibandingkan dengan sapi karapan K2. Hal ini dikarenakan sapi karapan K1 dipelihara dalam pemeliharaan yang intens dan memiliki exercise yang lebih sering dibandingkan dengan pemeliharaan sapi karapan K2. Sesuai dengan pendapat Rizqina et al. (2014), secara rataan nilai kecepatan lari sapi karapan yang exercise dan pemeliharaannya intens, lebih besar dari rataan nilai kecepatan lari sapi karapan yang exercise dan pemeliharaannya kurang. Faktor lain yang dapat mempengaruhi besarnya nilai rata-rata kecepatan lari sapi karapan adalah persepsi lingkungan (Adamzyck et al., 2015) yang mendukung tujuan pemeliharaan ternak artinya semakin banyak dilatih (persepsi lingkungan yang mendukung) berarti sapi mempunyai respon lari yang tinggi.

Berikut grafik rataan waktu tempuh dan kecepatan lari sapi karapan;

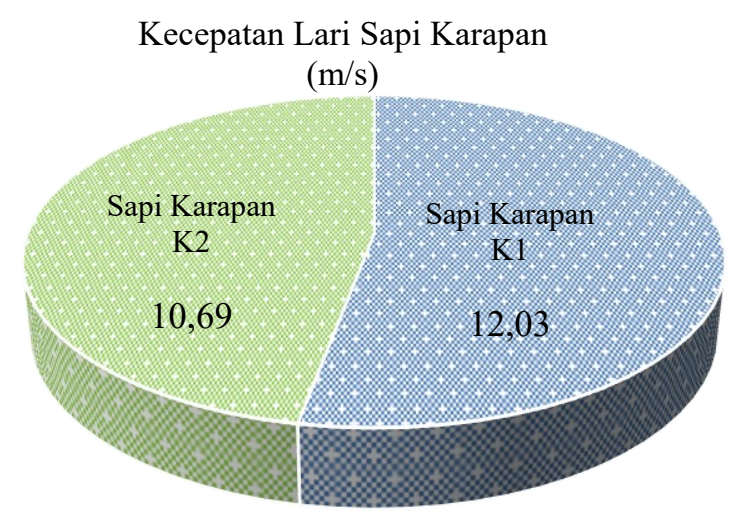

Gambar 1. Nilai rata-rata waktu tempuh (kiri) dan kecepatan lari (kanan) sapi karapan. 
Sapi karapan K1 mendapatkan treatment mandi dan penjemuran 3 kali dalam sehari sedangkan sapi karapan K2 hanya mendapatkan treatment pembersihan badan dan penjemuran 1 kali dalam sehari dengan pemijatan setiap tiga hari sekali. Proses pemandian dan penjemuran membuat kulit sapi lebih bersih dan sehat, sesuai pendapat Brito et al. (2020) kenyamanan ternak berarti erat hubungannya dengan animal walfare yang wajib untuk diperhatikan dalam memelihara ternak sekarang. Demikian juga dengan pemijatan berfungsi untuk melancarkan peredaran darah yang mempengaruhi fisiologis kenyamanan sapi, sesuai dengan pendapat Panjono et al. (2009) bahwa penjemuran yang dilakukan pada sapi mampu memberikan kenyamanan dan menunjukkan kondisi fisiologis ternak yang lebih baik dibandingkan dengan ternak sapi yang tidak dilakukan proses penjemuran. Menurut Mitchell et al. (2020) bahwa penjemuran dan pemijatan merupakan perlakuan biomedical terhadap ternak yang dapat menunjang kenyamanan ternak. Kenyamanan ternak erat hubungan dengan kesejahteraan ternak yang perlu diperhatikan agar ternak mempunyai respon positip terhadap pemiliknya (Adamczyk, 2018 dan Broom, 2011)

Menurut Trifena et al. (2011), berpendapat bahwa sifat kuantitatif sapi karapan sangat dipengaruhi oleh lingkungan diantaranya dari segi manajemen pemeliharaan dan pemberian pakan. Pemberian pakan yang bernutrisi baik dan jamu-jamuan alami yang diberikan secara teratur dapat menjadi sumber tenaga untuk bisa mempercepat lari dan membantu pembentukan perototan tubuh ternak sehingga ternak yang dipelihara akan memberikan hasil sesuai dengan target yang diharapkan. Chairdin, et al. (2015), menyatakan bahwa pemberian pakan dan manajemen pemeliharaan pada umumnya seragam dan berhubungan terhadap jangka waktu sapi berlari, sebagian besar pakan yang diberikan berupa rumput yang tersedia di daerah tersebut, daun jagung, jerami padi dan ditambah dengan jamu-jamuan). Diperkuat oleh Tennah et al. (2014) pemeliharaan hewan pacuan untuk lomba tidak hanya pertimbangan pendapatan tetapi perlu ditunjang oleh kesukaan/passion yang tidak dapat dinilai dengan uang.

Berdasarkan hasil pengamatan peneliti di lapangan menunjukkan bahwa jamu dari kedua kelompok sapi karapan sama dalam segi komposisi namun berbeda dalam frekuensi pemberiannya. Komposisi jamu yang diberikan oleh peternak kepada kedua kelompok sapi karapan (K1 dan K2) yang berbeda pemeliharaannya terdiri dari 15 butir telur ayam kampung, 1 sendok makan jahe bubuk, 1 sendok makan kunyit bubuk, 1 sendok makan temulawak bubuk dan 3 sendok makan kecap manis. Namun yang membedakan dalam pemberian jamu terhadap kedua kelompok sapi karapan adalah frekuensi pemberiannya. Sapi karapan yang pemeliharaannya intens (K1) diberi jamu satu kali sehari. Sedangkan sapi karapan yang pemeliharaannya kurang (K2) diberi jamu dua hari sekali. Aryogi dan Romjali (2006), perbedaan waktu pemberian jamu tersebut dapat mempengaruhi kecepatan lari sapi karapan.

Azuri dan Suwartono (2003) menyatakan bahwa pemeliharaan tidak cukup hanya dengan pemberian pakan terhadap sapi karapan saja. Sapi karapan diberi jamu dua bulan sekali berupa campuran telur, kopi, ditambah dengan kunyit, temulawak, temu hitam, bawang putih, jahe dan kencur. Pemberian jamu bertujuan untuk menjaga stamina sapi karapan sampai perlombaan dimulai. Selain itu, jamu merupakan obat tradisional untuk menjaga kesehatan ternak (Pushpangadan et al., 2016). Didukung pendapat Dong et al. (2009) bahwa pemberian jamu (herbal) juga diberikan pada ternak Yak jenis lokal dan hasil persilangan di Nepal.

\section{KESIMPULAN}

Kesimpulan dari penelitian ini adalah exercise dan pemeliharaan sapi Karapan mempengaruhi waktu tempuh dan kecepatan lari dengan rincian berikut waktu tempuh lari sapi Karapan dengan perlakuan exercise lebih rendah dari waktu tempuh lari sapi Karapan dengan perlakuan pemeliharaan atau maintanance. Kecepatan lari sapi Karapan perlakuan exercise lebih tinggi dari pada kecepatan lari sapi Karapan perlakuan pemeliharaan.

\section{DAFTAR PUSTAKA}

Adamczyk, K., A. G. Bruzda, J. nowicki, M. Gumulka, E. Molik, T. Schwarz, B. Earley, and C. Klocek. 2015. Perception of environment in farm animals - A review. Annals Animal Science 15 (3): 565-589.

Adamczyk, K. 2018. Dairy cattle welfare as a result of human-animal relationship - a review. Annals Animal Science. 18 (3): 601-622. DOI: 10.2478/aoas-2018-0013.

Aryogi dan Romjali, E. 2006, Potensi, Pemanfaatan dan Kendala Pengembangan 
Sapi Potong Lokal sebagai Kekayaan Plasma Nutfah Indonesia. Lokakarya Nasional Pengelolaan dan Perlindungan Sumber Daya Genetik di Indonesia.

Azuri, D.S dan Suwartono, E. 2003. Sapi Madura sebagai Ternak Kerja dan Penghasil Daging. PT. Balai Pustaka.

Brito L. F., H. R. Oliveria, B. R. McConn, A. P. Schinckel, A. Arrazola, J. N. M. frode, and J. S. Johnson. 2020. Large-Scale Phenotyping of Livestock Welfare in Commercial Production Systems: A New Frontier in Animal Breeding. Frontiers in Genetics. Vol. 1: 793. DOI: 10.3389/fgene.2020.00793

Broom, D.M. 2011. A history of animal welfare science. Acta Biotheoretica, 59, 121-137. DOI: $10.1007 / \mathrm{s} 10441-011-9123-3$

Chairdin, D.N, S. Maylinda dan M. Nasich. 2015. Karakteristik Sapi Sonok dan Sapi karapan pada Umur yang Berbeda di Kabupaten Pamekasan Pulau Madura. Ternak Tropika. 16 (1): 55- 60 .

Cole, J., and D. Fraser. 2018. Zoo Animal Welfare: The Human Dimension. Journal of Applied Animal Welfare Science. 21 (s1): 49-58.

Dong, S. K., L. Wen, L. Zhu, J. P. Lassoi, Z. L. Yan, K. K. Shrestha, D. Pariya, and E. Sharma. 2009. Indigenous yak and yakcattle crossbreed management in high altitude areas of northern Nepal: A case study from Rasuwa district. African Journal of Agricultural Research 4 (10): 957-967.

Kutsiyah, F. 2014. Sapi Madura: Pembibitan, Budaya dan Ekonomi Kreatif. Makalah Seminar Regional Sapi Madura. Universitas Madura.

Hefni, M. 2013. Tradisi Lisan Madura. STAIN Pamekasan. Madura.

Mitchell, M. D., M. A. Crookenden, K. Vaswani, J. R. Roche, and H. N. Peiris. 2020. The frontiers of biomedical science and its application to animal science in addressing the major challenges facing Australasian dairy farming. Animal Production Science, 60, 1-9. DOI: 10.1071/AN18579
Nielsen B. D, K. K. Turner, B.A. Ventura, A.D. Woodward, and C.I. O'Connor. 2006 Racing speeds of Quarter horses, Thoroughreds and Arabians. Equine Exercise Physiology 7, Equine vet. J., Suppl. 36: 128-132.

Panjono, B. P. Widyobroto, B. Suhartanto, dan E. Baliarti. 2009. Pengaruh Penjemuran terhadap Kenyamanan dan Kinerja Produksi Sapi Peranakan Ongole. Buletin Peternakan. 33(1): 17-22.

Pushpangadan, P., T.P. Ijinu, A. J. Bincy, S. Anzar, T. Aswany, M.A. Chitra, K. Harsha, P. Sreedevi, and V. George. 2016. Traditional Medicine in livestock management. J. Traditional and Folk Practices. 4(1): 43 - 49 .

Rizqina, L. Jannah, Isbandi, Erianto, S. I. Santoso dan E. Rianto. 2014. The Potential of Madura Cattle as A Source of Family Income in Sapudi Island. Journal Anim. Sci. East Java.

Sumadi, I. K., D. Sastradipradja, S. Hartini, B. Kiranadi, H. Martojo, dan Kartiarso. 2006. Beberapa respon fisiologis Kerbau pacuan yang mendapat lama waktu latihan berbeda. Jurnal Protein. 13(1): 23-30.

Tennah S., F. Farnir, N. Kafidi, I. N. Nsangou, P. Leroy, N. Antoine-Moussiaux. 2014. Selective breeding of Arabian and Thoroughbred racehorses in Algeria: perceptions, objectives and practices of owners-breeders. Revista Brasileira de Zootecnia 43(4):188-196

Trifena, I.G.S. Budisatria, dan T. Hartatik. 2011. The Phenotypic Changes of First Filial and Backross of Ongole Grade, Simpo and Limpo Cows. Buletin of Animal Science. 35(1): 11-16.

Widi, T.S.M., dan T. Hartatik. 2009. The Characteristics and Performances of Sonok Compared to Karapan Cows as Important Consideration of Madura Cattle. Book of Abstracts. Biophysical and SocioEconomic Frame Conditions for the Sustainable Management of Natural Resources: International Research on Food Security, Natural Resources Management and Rural Development, Tropentag, October 6-8, 2009, Hamburg. 